\title{
Wpływ procesów cięcia termicznego i strumieniem wody na właściwości i jakość powierzchni ciętych stali niskostopowych o wysokiej granicy plastyczności
}

\author{
An influence of thermal and water cutting \\ processes on properties and quality \\ of low alloy high strength steels
}

\section{Streszczenie}

W artykule opisano wpływ procesu cięcia strumieniem tlenu, plazmą powietrzną HD, laserem oraz strumieniem wody na jakość powierzchni stali obrobionej termomechanicznie S 700MC oraz ulepszonej cieplnie S 690QL o grubości $10 \mathrm{~mm}$. Ocenie poddano jakość powierzchni po cięciu (odchyłkę prostopadłości, chropowatość powierzchni, kąt ukosu), szerokość szczeliny cięcia, sposób przebijania oraz zmiany strukturalne i zmiany twardości zachodzące przy powierzchni cięcia.

\section{Wstęp}

Coraz częściej na konstrukcje spawane stosowane są drobnoziarniste stale niskostopowe otrzymywane w procesie obróbki termomechanicznej lub ulepszania cieplnego $[1 \div 3$ ]. Nowoczesne stale konstrukcyjne swoje właściwości zawdzięczają złożonym procesom wytwarzania, od których zależą ich właściwości wytrzymałościowe oraz spawalność (rys. 1) [4].

Cięcie jest operacją technologiczną, od której najczęściej zaczyna się cały proces wytwórczy. Zmiany zachodzące podczas cięcia $w$ materiale mogą mieć zatem istotny wpływ na jakość elementów. Rozwój metod cięcia następuje wskutek coraz większych wymagań, poczynając od cięcia prostoliniowego, przez cięcie 2D, do cięcia 3D. Odpowiedni wybór metody cięcia

Dr inż. Jacek Górka, mgr inż. Rafał Skiba - Politechnika Śląska, Gliwice.

\section{Abstract}

In this paper an influence of oxygen, HTPAC plasma, laser and water cutting on $10 \mathrm{~mm}$ thickness plates from S 700MC and S 690QL steel surface quality was described. Quality assessment was measured by surface quality (square deviation, coarseness, angle chamfer), width of cutting gap, perforation method, structural and hardness changes in the area near the cutting surface.

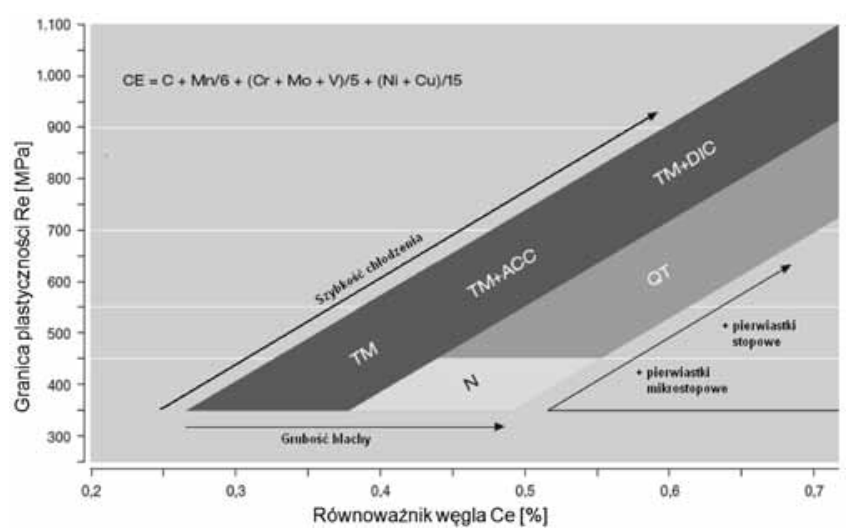

Rys. 1. Zależność między równoważnikiem węgla a granicą plastyczności $R$ stali uzyskanych $w$ różnych procesach wytwarzania: $\mathrm{N}$ - walcowanie normalizujące, TM - walcowanie termomechanicznie, ACC - przyspieszone chłodzenie, DIC - bezpośrednie intensywne chłodzenie, QT - ulepszanie cieplne [4]

Fig. 1. Relation between carbon equivalent and yield stress $R_{e}$ of different manufacturing processes of steels: $\mathrm{N}$ - normalizing rolled, TM - thermomechanically rolled, ACC - accelerated cooled, DIC - direct intensive cooled, QT - quenched and tempered 
zależy od wymagań i możliwości technicznych, tj. rodzaju i grubości ciętego materiału, jakości cięcia, tolerancji wymiarowych, odchyłki prostopadłości, prędkości cięcia czy kształtu wycinanego elementu oraz od czynników ekonomicznych, do których zalicza się koszt inwestycji, koszt eksploatacji, efektywność procesu

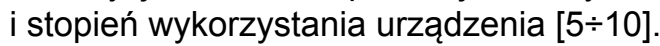

\section{Badania własne}

Celem badań było określenie wpływu procesu cięcia strumieniem tlenu, plazmą powietrzną HD, wiązką promieniowania laserowego oraz strumieniem wody na jakość powierzchni ciętych stali: obrobionej termomechanicznie S 700MC oraz ulepszonej cieplnie S 690QL

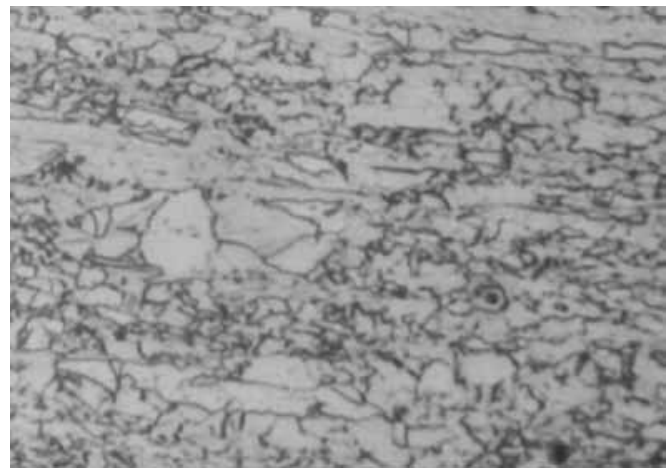

Rys. 2. Struktura ferrytyczno-bainityczna stali obrobionej termomechanicznie S 700MC

Fig. 2. Ferrite-bainitic structure of termomechanically controlled rolled S 700MC steel

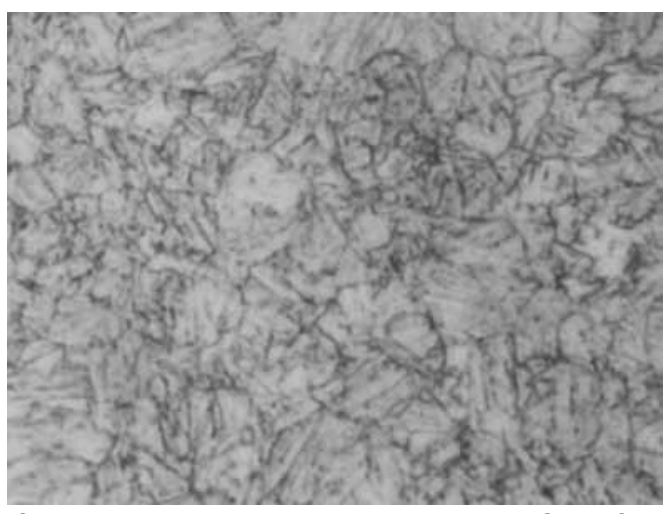

Rys. 3. Struktura martenzytu odpuszczonego stali S $690 \mathrm{QL}$

Fig. 3. Drawing temper marteniste structure of S $690 \mathrm{QL}$ steel

o grubości $10 \mathrm{~mm}$. Skład chemiczny oraz właściwości mechaniczne badanych stali zawarto $\mathrm{w}$ tablicy I, a strukturę przedstawiono na rysunkach 2 i 3 .

\section{Proces cięcia}

Proces cięcia został przeprowadzony przy najlepszych parametrach dla grubości blachy $10 \mathrm{~mm}$ (tabl. II). Długość krawędzi ciętej wynosiła 200 mm. Cięcie strumieniem tlenu wykonano na stanowisku wyposażonym w urządzenie Messer OmniMat ze sterowaniem Global Control i palnikiem Alfa. Cięcie plazmowe łukiem zależnym o zawężonym strumieniu plazmy HTPAC blach przeprowadzono na urządzeniu HYPERTHERM HD 3070 współpracującym ze stołem portalowym

Tablica I. Skład chemiczny i właściwości mechaniczne stali S 700MC i S 690QL

Table I. Chemical composition and mechanical properties of S 700MC and S 690QL steel plates

\begin{tabular}{|c|c|c|c|c|c|c|c|c|c|c|c|}
\hline \multicolumn{12}{|c|}{ Zawartość pierwiastków, \% } \\
\hline & $\mathrm{C}$ & $\mathrm{Si}$ & $\mathrm{Mn}$ & $\mathrm{P}$ & $\mathrm{S}$ & $\mathrm{Cr}$ & $\mathrm{Nb}$ & V & $\mathrm{Ti}$ & $\mathrm{Ni}$ & Mo \\
\hline S 700MC & 0,06 & 0,17 & 1,68 & 0,008 & 0,003 & - & 0,047 & 0,006 & 0,122 & - & 0,006 \\
\hline S 690QL & 0,20 & 0,50 & 1,60 & 0,02 & 0,02 & 1,0 & - & 0,10 & - & 1,50 & 0,60 \\
\hline \multicolumn{12}{|c|}{ Właściwości mechaniczne } \\
\hline & \multicolumn{4}{|c|}{ Wytrzymałość na rozciąganie, $\mathrm{R}_{\mathrm{m}}, \mathrm{MPa}$} & \multicolumn{4}{|c|}{ Granica plastyczności, $\mathrm{R}_{\mathrm{e}}, \mathrm{MPa}$} & \multicolumn{3}{|c|}{ Wydłużenie, $A_{5}, \%$} \\
\hline S 700MC & \multicolumn{4}{|c|}{822} & \multicolumn{4}{|c|}{768} & \multicolumn{3}{|c|}{19} \\
\hline S 690QL & \multicolumn{4}{|c|}{810} & \multicolumn{4}{|c|}{730} & \multicolumn{3}{|c|}{14} \\
\hline
\end{tabular}

Tablica II. Parametry procesu cięcia strumieniem tlenu, plazmą powietrzną HD, laserem, strumieniem wody stali S 700MC oraz stali S 690QL Table II. Parameters of oxygen, HTPAC plasma, laser and water cutting of S 700MC and S 690QL steel

\begin{tabular}{|c|c|c|c|c|c|c|c|}
\hline \multicolumn{8}{|c|}{ Proces cięcia strumieniem tlenu } \\
\hline \multicolumn{2}{|c|}{$\begin{array}{l}\text { Ciśnienie tlenu } \\
\text { tnącego, MPa }\end{array}$} & \multicolumn{2}{|c|}{$\begin{array}{c}\text { Ciśnienie acetylenu, } \\
\mathrm{MPa}\end{array}$} & $\begin{array}{c}\text { Prędkość cięcia, } \\
\text { m/min }\end{array}$ & \multicolumn{2}{|c|}{$\begin{array}{l}\text { Dysza tlenowa, } \\
\text { mm }\end{array}$} & $\begin{array}{c}\text { Odległość dyszy, } \\
\mathrm{mm}\end{array}$ \\
\hline \multicolumn{2}{|l|}{0,5} & \multicolumn{2}{|r|}{0,045} & 0,57 & \multicolumn{2}{|c|}{$7-15$} & 8 \\
\hline \multicolumn{8}{|c|}{ Proces cięcia plazmą powietrzną HD } \\
\hline $\begin{array}{c}\text { Natężenie } \\
\text { prądu, A }\end{array}$ & \multicolumn{2}{|c|}{$\begin{array}{c}\text { Napięcie łuku, } \\
\text { V }\end{array}$} & $\begin{array}{l}\text { Prędkość cię- } \\
\text { cia, m/min }\end{array}$ & $\begin{array}{l}\text { Ciśnienie gazu pla- } \\
\text { zmowego, MPa }\end{array}$ & Rodzaj elektrody & $\begin{array}{l}\text { Średnica dyszy } \\
\text { tnącej, mm }\end{array}$ & $\begin{array}{l}\text { Odległość pal- } \\
\text { nika, mm }\end{array}$ \\
\hline 100 & \multicolumn{2}{|r|}{150} & 3,0 & 0,8 & cyrkonowa & 1 & 4 \\
\hline \multicolumn{8}{|c|}{ Proces cięcia wiązką laserową } \\
\hline \multicolumn{2}{|c|}{ Moc wiązki, W } & \multicolumn{2}{|c|}{ Prędkość cięcia, m/min } & Ciśnienie gazu, MPa & Rodzaj gazu & \multicolumn{2}{|c|}{ Odległość głowicy, mm } \\
\hline \multicolumn{2}{|l|}{4800} & \multicolumn{2}{|c|}{2,4} & 0,8 & tlen & \multicolumn{2}{|c|}{1,5} \\
\hline \multicolumn{8}{|c|}{ Proces cięcia strumieniem wody } \\
\hline $\begin{array}{c}\text { Ciśnienie } \\
\text { wody, MPa }\end{array}$ & & $\begin{array}{l}\text { rędkość } \\
\text { cia, } \mathrm{m} / \mathrm{min}\end{array}$ & $\begin{array}{l}\text { Średnica dyszy } \\
\text { tnącej, mm }\end{array}$ & $\begin{array}{l}\text { Średnica dyszy } \\
\text { wodnej, mm }\end{array}$ & $\begin{array}{c}\text { Rodzaj i ziarni- } \\
\text { stość proszku, } \mu \mathrm{m}\end{array}$ & $\begin{array}{l}\text { Wydajność podawa- } \\
\text { nia proszku, g/min }\end{array}$ & $\begin{array}{l}\text { Odległość } \\
\text { dyszy, mm }\end{array}$ \\
\hline 380 & & 2,1 & 0,76 & 1,5 & „Garnet”, 80 & 480 & 5 \\
\hline
\end{tabular}


konstrukcji bramowej VANAD Proxima. Do cięcia wiązką lasera wykorzystano laser Trumpf TruLaser 5060 (L10) o maksymalnej mocy 5000 W. Gazem towarzyszącym był tlen. Proces cięcia strumieniem wody przeprowadzono na maszynie NC 3520 D.

\section{Ocena jakości powierzchni ciętych}

Oceny jakości powierzchni ciętych strumieniem tlenu, plazmą powietrzną HD, wiązką laserową oraz strumieniem wody badanych stali dokonano na podstawie normy ISO 9013:2002, wg której ocenie podlega chropowatość powierzchni oraz tolerancja prostopadłości lub pochylenia powierzchni cięcia. Pomiar chropowatości Rz przeprowadzono w kierunku zgodnym z kierunkiem cięcia w pięciu miejscach próbki, długość odcinka pomiarowego wynosiła 12,5 mm, natomiast długość odcinka elementarnego $2,5 \mathrm{~mm}$ (tabl. III). Urządzeniem stosowanym do pomiaru chropowatości był profilometr Surftest 402 firmy Mitutoyo. Pomiar odchyłki prostopadłości u przeprowadzono w odstępach $20 \mathrm{~mm}$ w trzech miejscach próbki, kąt ukosu zmierzono kątomierzem optycznym (tabl. III).

W celu porównania geometrycznych cech powierzchni cięcia określono średnicę otworu przebicia oraz geometrię rowka ciętego (szerokość górnej i dolnej szczeliny cięcia) i kąt ukosu (tabl. IV).

Tablica III. Ocena jakości powierzchni ciętych stali S 700 MC oraz S 690QL o grubości 10 mm wg normy ISO 9013:2002

Table III. Quality assessment of $10 \mathrm{~mm}$ thickness S $700 \mathrm{MC}$ and S 690QL steel cut plates in acc. to ISO 9013:2002 standard

\begin{tabular}{|c|c|c|c|c|c|c|c|c|c|c|}
\hline \multirow[t]{2}{*}{ Metoda cięcia } & \multicolumn{2}{|c|}{$\begin{array}{c}\text { Odchyłka prostopa- } \\
\text { dłości } \mathrm{u}_{\mathrm{s} r}, \mathrm{~mm}\end{array}$} & \multicolumn{2}{|c|}{$\begin{array}{c}\text { Pole } u \text { wg } \\
\text { ISO 9013: } 2002\end{array}$} & \multicolumn{2}{|c|}{$\begin{array}{c}\text { Chropowatość } \\
\text { powierzchni } \mathrm{Rz}_{\mathrm{sr}}, \mu \mathrm{m}\end{array}$} & \multicolumn{2}{|c|}{$\begin{array}{c}\text { Pole Rz } \\
\text { wg ISO } 9013: 2002\end{array}$} & \multicolumn{2}{|c|}{$\begin{array}{c}\text { Kąt } \\
\text { ukosu, }^{\circ}\end{array}$} \\
\hline & MC & QL & $\mathrm{MC}$ & QL & $\mathrm{MC}$ & QL & MC & QL & MC & QL \\
\hline Cięcie strumieniem tlenu & 0,45 & 0,30 & 3 & 3 & 15,80 & 20,80 & 1 & 2 & $2^{\circ} 30^{\prime}$ & $1^{\circ} 30^{\prime}$ \\
\hline Cięcie plazmą powietrzną HD & 0,82 & 0,49 & 4 & 3 & 9,30 & 6,30 & 1 & 1 & $2^{\circ} 20^{\prime}$ & $20^{\prime}$ \\
\hline Cięcie wiązką laserową & 0,11 & 0,12 & 1 & 1 & 13,50 & 18,00 & 1 & 2 & $1^{\circ}$ & $30^{\prime}$ \\
\hline Cięcie strumieniem wody & 0,25 & 0,22 & 2 & 2 & 20,30 & 19,90 & 2 & 2 & $30^{\prime}$ & $1^{\circ} 30^{\prime}$ \\
\hline
\end{tabular}

Tablica IV. Ocena geometrycznych cech powierzchni ciętych stali S 700MC oraz S 690QL o grubości $10 \mathrm{~mm}$

Table IV. Geometrical attributes assessment of $10 \mathrm{~mm}$ thickness S 700MC and S 690QL steel cut plates

\begin{tabular}{|c|c|c|c|c|c|c|c|c|c|c|}
\hline \multirow[t]{2}{*}{ Metoda cięcia } & \multicolumn{2}{|c|}{$\begin{array}{c}\text { Szerokość górnej } \\
\text { szczeliny cięcia, mm }\end{array}$} & \multicolumn{2}{|c|}{$\begin{array}{c}\text { Szerokość dolnej } \\
\text { szczeliny cięcia, mm }\end{array}$} & \multicolumn{2}{|c|}{$\begin{array}{l}\text { Górna średnica otwo } \\
\text { ru przebicia, } \mathrm{mm}\end{array}$} & \multicolumn{2}{|c|}{$\begin{array}{c}\text { Dolna średnica otwo } \\
\text { ru przebicia, mm }\end{array}$} & \multicolumn{2}{|c|}{$\begin{array}{l}\text { Powstanie nacieków na } \\
\text { dolnej krawędzi cięcia }\end{array}$} \\
\hline & MC & QL & $\mathrm{MC}$ & $\mathrm{QL}$ & MC & QL & $\mathrm{MC}$ & $\mathrm{QL}$ & MC & QL \\
\hline Cięcie strumieniem tlenu & 1,75 & 1,65 & 1,68 & 1,59 & - & - & - & - & małe & małe \\
\hline Cięcie plazmą powietrzną HD & 1,95 & 2,0 & 1,29 & 1,09 & 4,62 & 5,19 & 2,87 & 3,27 & duże & małe \\
\hline Cięcie wiązką laserową & 0,48 & 0,52 & 0,48 & 0,45 & 4,09 & 4,08 & 3,93 & 3,92 & brak & brak \\
\hline Cięcie strumieniem wody & 0,85 & 1,2 & 0,78 & 0,82 & - & - & - & - & brak & brak \\
\hline
\end{tabular}

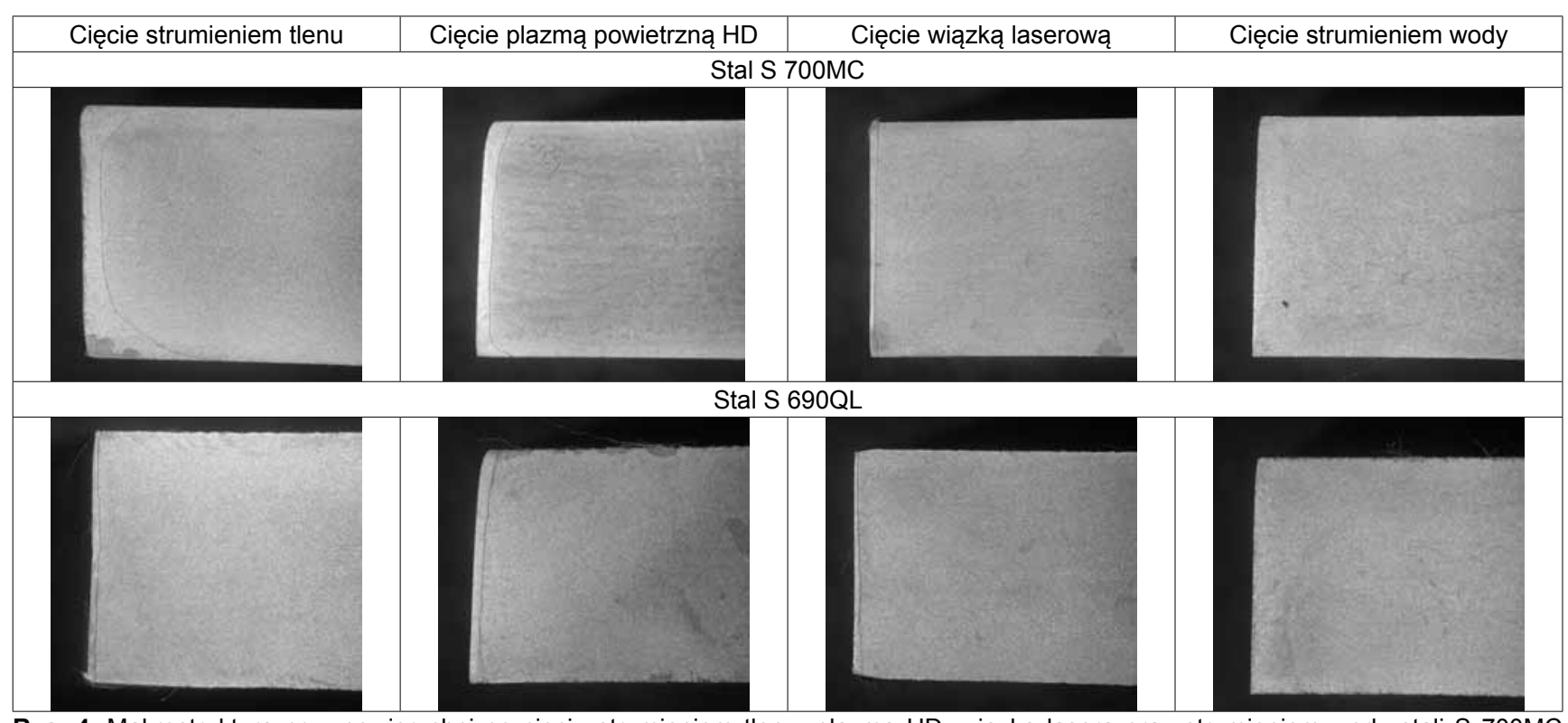

Rys. 4. Makrostruktura przy powierzchni po cięciu strumieniem tlenu, plazmą HD, wiązką lasera oraz strumieniem wody stali S 700MC oraz S 690QL, trawienie - odczynnik Adlera

Fig. 4. Macrostructure of area near the surface after oxygen, HTPAC, laser and water cutting of S 700MC and S 690QL steel, etching - Adler's chemical reagent 


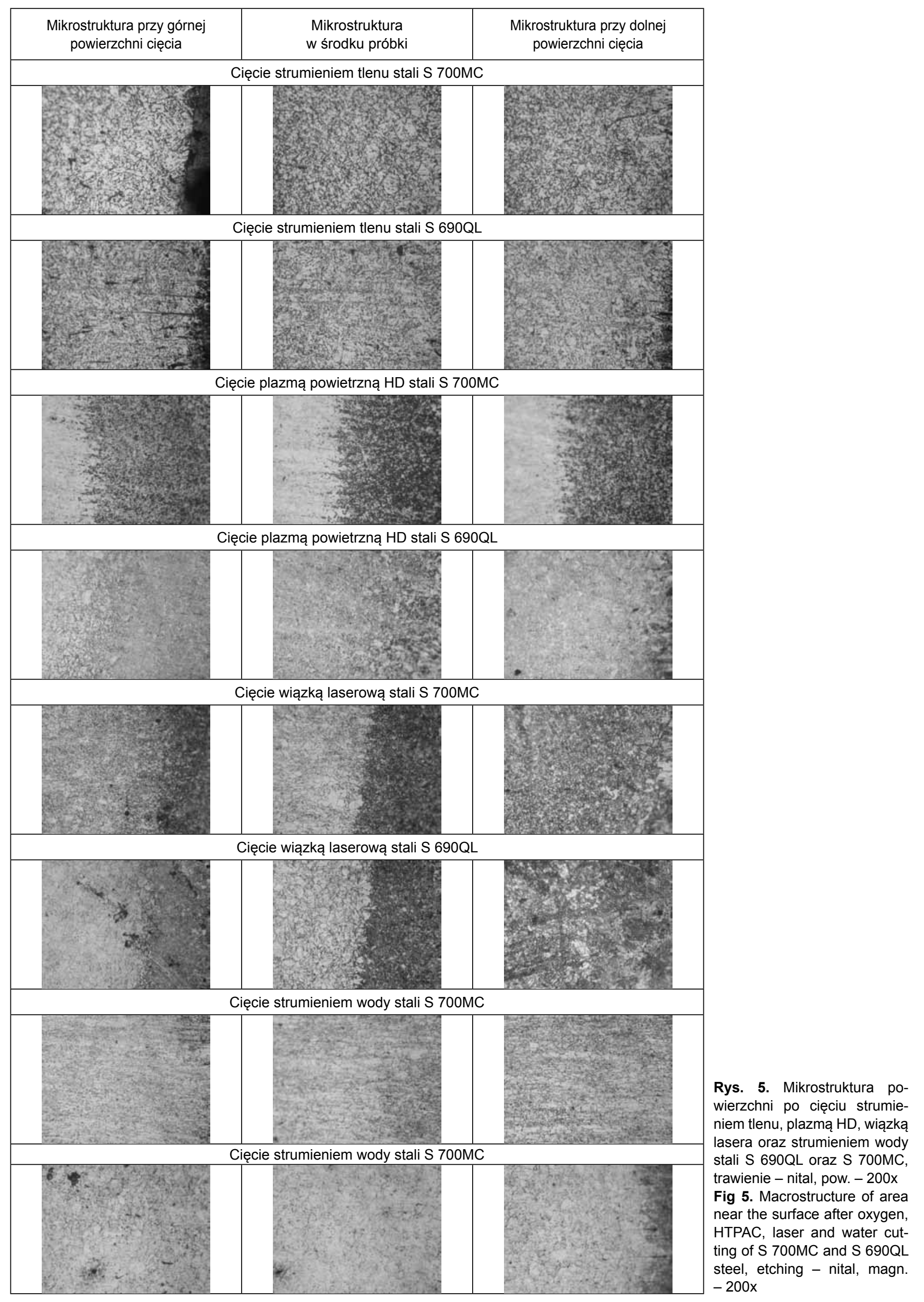




\section{Badania metalograficzne}

W celu określenia szerokości strefy wpływu ciepła powstałej po cięciu stali S 700MC oraz S 690QL wykonano badania makroskopowe przy użyciu mikroskopu stereoskopowego Olympus SZX9 (rys. 4). Ocenę wpływu procesów cięcia na zmiany strukturalne przy powierzchni cięcia przeprowadzono na podstawie badań mikroskopowych przy użyciu mikroskopu świetlnego Olympus PME 3. Badania mikroskopowe zostały wykonane w trzech miejscach próbki: przy górnej powierzchni cięcia, w środku próbki oraz przy dolnej krawędzi (rys. 5).

\section{Pomiar twardości}

Pomiar twardości po cięciu wykonano metodą Vickersa na mikrotwardościomierzu Wilson Wolpert 401

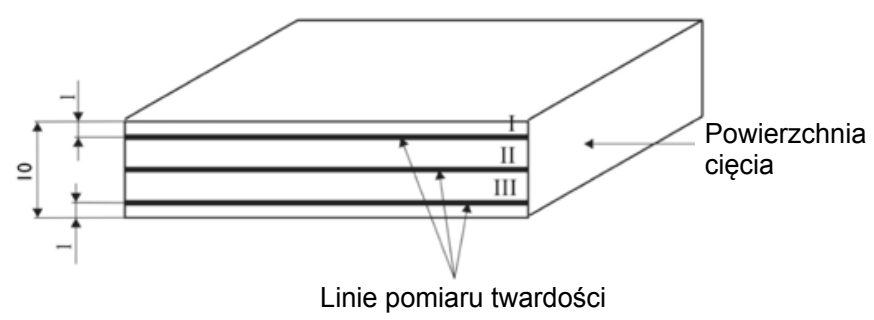

Rys. 6. Linie pomiaru twardości ciętych blach

Fig 6. Hardness measurement lines of cut plates

MVD przy obciążeniu $100 \mathrm{~g}$; czas działania wgłębnika - 15 s. Pomiar przeprowadzono wzdłuż trzech linii pomiarowych prostopadłych do powierzchni cięcia. Sposób pomiaru twardości przedstawiono na rysunku 6 . Wyniki pomiarów twardości zestawiono $\mathrm{w}$ tablicach $\mathrm{V}$ i VI.

Tablica V. Twardość HV0,1 po cięciu blachy S 700MC

Table V. HV0,1 hardness after cutting S 700MC steel plate

\begin{tabular}{|c|c|c|c|c|c|c|c|c|c|c|c|c|}
\hline \multirow{3}{*}{$\begin{array}{l}\text { Odległość pomiaru } \\
\text { od powierzchni } \\
\text { cięcia, mm }\end{array}$} & \multicolumn{3}{|c|}{$\begin{array}{c}\text { Twardość HV0,1 } \\
\text { po cięciu strumieniem tlenu }\end{array}$} & \multicolumn{3}{|c|}{$\begin{array}{l}\text { Twardość HV0,1 po cięciu } \\
\text { plazmą powietrzną }\end{array}$} & \multicolumn{3}{|c|}{$\begin{array}{c}\text { Twardość HV0,1 po cięciu } \\
\text { wiązką laserową }\end{array}$} & \multicolumn{3}{|c|}{$\begin{array}{l}\text { Twardość HV0,1 po cięciu } \\
\text { strumieniem wody }\end{array}$} \\
\hline & \multicolumn{12}{|c|}{ Linia pomiaru wg rysunku 6} \\
\hline & 1 & II & III & 1 & II & III & 1 & II & III & 1 & II & III \\
\hline 0,1 & 296 & 301 & 287 & 366 & 366 & 376 & 404 & 362 & 386 & 311 & 303 & 307 \\
\hline 0,2 & 284 & 271 & 273 & 346 & 365 & 344 & 306 & 372 & 331 & 297 & 296 & 299 \\
\hline 0,3 & 261 & 264 & 253 & 308 & 310 & 323 & 285 & 339 & 295 & 289 & 287 & 287 \\
\hline 0,4 & 267 & 248 & 270 & 299 & 290 & 303 & 285 & 285 & 284 & 286 & 285 & 287 \\
\hline 0,5 & 257 & 250 & 261 & 309 & 295 & 291 & 278 & 281 & 281 & 284 & 285 & 285 \\
\hline 0,6 & 260 & 243 & 258 & 284 & 285 & 285 & 274 & 274 & 276 & 282 & 284 & 285 \\
\hline 0,7 & 235 & 276 & 253 & 280 & 280 & 279 & - & - & - & - & - & - \\
\hline 0,8 & 272 & 281 & 270 & 276 & 273 & 273 & - & - & - & - & - & - \\
\hline 0,9 & 289 & 312 & 296 & - & - & - & - & - & - & - & - & - \\
\hline 1,0 & 294 & 293 & 284 & - & - & - & - & - & - & - & - & - \\
\hline 1,1 & 278 & 290 & 291 & - & - & - & - & - & - & - & - & - \\
\hline 1,2 & 279 & 283 & 280 & - & - & - & - & - & - & - & - & - \\
\hline 1,3 & 280 & 280 & 279 & - & - & - & - & - & - & - & - & - \\
\hline 1,4 & 284 & 276 & 275 & - & - & - & - & - & - & - & - & - \\
\hline 1,5 & 283 & 273 & 275 & - & - & - & - & - & - & - & - & - \\
\hline
\end{tabular}

Tablica VI. Twardość HV0,1 po cięciu blachy S 690QL

Table VI. HV0,1 hardness after cutting S 690QL steel plate

\begin{tabular}{|c|c|c|c|c|c|c|c|c|c|c|c|c|}
\hline \multirow{3}{*}{$\begin{array}{l}\text { Odległość pomiaru } \\
\text { od powierzchni } \\
\text { cięcia, mm }\end{array}$} & \multicolumn{3}{|c|}{$\begin{array}{l}\text { Twardość HV0,1 po cięciu } \\
\text { strumieniem tlenu }\end{array}$} & \multicolumn{3}{|c|}{$\begin{array}{l}\text { Twardość HV0,1 po cięciu } \\
\text { plazmą powietrzną }\end{array}$} & \multicolumn{3}{|c|}{$\begin{array}{c}\text { Twardość HV0,1 po cięciu } \\
\text { wiązką laserową }\end{array}$} & \multicolumn{3}{|c|}{$\begin{array}{l}\text { Twardość HV0,1 po cięciu } \\
\text { strumieniem wody }\end{array}$} \\
\hline & \multicolumn{12}{|c|}{ Linia pomiaru wg rysunku 6} \\
\hline & 1 & II & III & 1 & II & III & 1 & II & III & 1 & II & III \\
\hline 0,1 & 292 & 287 & 273 & 426 & 404 & 395 & 458 & 466 & 466 & 299 & 311 & 306 \\
\hline 0,2 & 298 & 267 & 272 & 391 & 462 & 425 & 426 & 445 & 443 & 283 & 299 & 298 \\
\hline 0,3 & 283 & 258 & 263 & 425 & 467 & 437 & 333 & 321 & 269 & 285 & 286 & 286 \\
\hline 0,4 & 227 & 238 & 255 & 399 & 409 & 399 & 285 & 283 & 280 & 285 & 285 & 285 \\
\hline 0,5 & 233 & 229 & 242 & 348 & 290 & 303 & 279 & 280 & 278 & 286 & 285 & 284 \\
\hline 0,6 & 208 & 225 & 240 & 292 & 285 & 285 & 276 & 275 & 274 & 284 & 284 & 283 \\
\hline 0,7 & 216 & 214 & 247 & 285 & 280 & 281 & - & - & - & - & - & - \\
\hline 0,8 & 201 & 200 & 238 & 279 & 275 & 276 & - & - & - & - & - & - \\
\hline 0,9 & 185 & 202 & 223 & - & - & - & - & - & - & - & - & - \\
\hline 1,0 & 216 & 220 & 216 & - & - & - & - & - & - & - & - & - \\
\hline 1,1 & 228 & 222 & 241 & - & - & - & - & - & - & - & - & - \\
\hline 1,2 & 267 & 244 & 251 & - & - & - & - & - & - & - & - & - \\
\hline 1,3 & 274 & 275 & 258 & - & - & - & - & - & - & - & - & - \\
\hline 1,4 & 278 & 280 & 274 & - & - & - & - & - & - & - & - & - \\
\hline 1,5 & 284 & 285 & 280 & - & - & - & - & - & - & - & - & - \\
\hline
\end{tabular}


Analiza wyników badań

\section{Ocena jakości powierzchni i wymiarów szczeliny cięcia}

Norma ISO 9013:2002 przy ocenie powierzchni po cięciu termicznym bierze pod uwagę chropowatość powierzchni oraz tolerancję prostopadłości powierzchni cięcia. Pozostałe parametry geometryczne (wielkość szczeliny cięcia, kąt ukosu, średnica otworu przebicia) traktowane są pomocniczo. Ze względu na brak normy dotyczącej jakości powierzchni ciętych strumieniem wody, jakość tych powierzchni oceniono wg normy ISO 9013:2002.

Wykonana ocena jakości powierzchni po cięciu stali S 700MC pozwoliła stwierdzić, że jakość powierzchni ciętych laserem zawiera się w obszarze (polu) 1-1, plazmą HD 4-1, strumieniem tlenu 3-1, natomiast przy cięciu strumieniem wody w 2-2. Dla stali S 690QL otrzymano pola odpowiednio: 1-2, 3-1, 3-2, 2-2. Analiza chropowatości powierzchni obu stali wykazała, że jest ona zależna od procesu cięcia i materiału ciętego. Najniższe wartości chropowatości $(10 \mu \mathrm{m})$ otrzymano podczas cięcia plazmą powietrzną HD. W przypadku pozostałych procesów wartość ta wynosiła $15 \div 20 \mu \mathrm{m}$.

Maksymalne wartości odchyłki uzyskano podczas cięcia plazma powietrzna HD i wynosiła ona dla stali S 690QL ok. 0,5 mm, a dla S 700MC - 0,82 mm. Minimalną wartość uzyskano przy cięciu wiązką laserową (ok. 0,1 mm). Przy cięciu strumieniem wody i strumieniem tlenu uzyskano odpowiednio wartości w przedziale $0,22 \div 0,25 \mathrm{~mm}$ oraz $0,30 \div 0,45 \mathrm{~mm}$.

Największą szczelinę cięcia uzyskano przy zastosowaniu plazmy powietrznej HD i strumienia tlenu. Szczelina kształtem zbliżona jest do V. Szerokość górnej części szczeliny cięcia plazmą powietrzną HD wynosi ok. $2 \mathrm{~mm}$, natomiast po cięciu strumieniem tlenu - ok. 1,7 mm. Dla porównania wielkość szczeliny powstałej w wyniku procesu cięcia wiązką laserową wynosi tylko ok. $0,5 \mathrm{~mm}$, a dla cięcia strumieniem wody od $0,85 \mathrm{~mm}$ (stal S 700MC) do ok. 1,2 mm (stal S 690QL). Powierzchnie szczeliny $\mathrm{w}$ cięciu laserem są prawie równoległe - różnica pomiędzy górną i dolną częścią szczeliny dla stali S $690 \mathrm{QL}$ wynosi $0,07 \mathrm{~mm}$, a dla stali $\mathrm{S} 700 \mathrm{MC}-0,03 \mathrm{~mm}$. Różnica ta jest nieco większa w przypadku stali ciętych strumieniem wody (S 690QL $-0,38 \mathrm{~mm}$; S 700MC - 0,07 mm).

\section{Zmiany strukturalne przy powierzchni cięcia}

Przeprowadzone badania metalograficzne makroi mikroskopowe oraz pomiary twardości powierzchni ciętych pozwoliły określić szerokość SWC i określić charakter zmian struktury przy powierzchni cięcia. Podczas cięcia wiązką laserową stali S 690QL przy powierzchni cięcia powstaje warstwa martenzytu niskowęglowego o twardości do $460 \mathrm{HV} 0,1$. Szerokość tej warstwy wynosi ok. 0,3 mm. Podczas cięcia blachy ze stali S 700MC powstaławarstwa bainitycznao twardości niższejniż w przypadku stali S 690QL, która wynosi ok. 360 $4405 \mathrm{HV0}$,1. Za tą warstwą o szerokości ok. 0,6 mm obserwowano drobnoziarnistą strukturę bainityczno-ferrytyczną (materiał rodzimy) o twardości $280 \mathrm{HV} 0,1$.

Podczas cięcia stali S 690QL plazmą HD przy powierzchni cięcia powstaje warstwa martenzytu niskowęglowego o twardości do 467 HV0,1 podobnie jak w przypadku procesu cięcia wiązką lasera, jednak szerokość tej warstwy jest znacznie większa (ok. 0,6 mm). Analogicznie jest w przypadku cięcia stali S 700MC, z tym że twardość warstwy bainitycznej wynosi $360 \div 375 \mathrm{HV} 0$,1. Proces cięcia strumieniem tlenu stali S 690QL spowodował obniżenie twardości strefy wpływu ciepła nawet do $185 \mathrm{HV0}, 1$ (proces odpuszczania) przy wielkości tej strefy ok. 1,3 mm. Podobnie stało się w przypadku cięcia stali S 700MC, gdzie minimalna twardość SWC wyniosła ok. 235 HV0,1 (częściowa rekrystalizacja ziarna), podczas gdy wielkość tej strefy wyniosła również ok. 1,2 mm. Proces cięcia strumieniem wody nie spowodował zmian strukturalnych ciętych blach, jedynie wpłynął na zwiększenie twardości materiałów bezpośrednio przy powierzchni cięcia o ok. $30 \mathrm{HV0,1}$ w wyniku utwardzenia zgniotowego. Wpływ procesów cięcia na zmiany strukturalne przy powierzchni ciętej zawarto w tablicy VII.

Tablica VII. Struktura materiału po procesie cięcia strumieniem tlenu, plazmą powietrzną HD, wiązką laserową oraz strumieniem wody Table VII. Material structures after oxygen, HTPAC plasma, laser and water cutting

\begin{tabular}{|c|c|c|c|c|}
\hline \multirow{2}{*}{$\begin{array}{c}\text { Rodzaj materiału } \\
\text { ciętego }\end{array}$} & \multirow{2}{*}{ Materiał rodzimy } & góra blachy & struktura materiału przy powierzchni cięcia \\
\cline { 3 - 5 } & \multicolumn{5}{|c|}{ cięcie strumieniem tlenu } \\
\hline S 700MC & ferryt + bainit drobnoziarnisty & ferryt + bainit & ferryt + bainit & fér blachy \\
\hline S 690QL & martenzyt odpuszczony & martenzyt niskowęglowy & martenzyt niskowęglowy & martenzyt niskowęglowy \\
\hline \multicolumn{5}{|c|}{ cięcie plazmą powietrzną HD } \\
\hline S 700MC & ferryt + bainit drobnoziarnisty & bainit drobnoziarnisty & bainit drobnoziarnisty & bainit drobnoziarnisty \\
\hline S 690QL & martenzyt odpuszczony & martenzyt niskowęglowy & martenzyt niskowęglowy & martenzyt niskowęglowy \\
\hline \multicolumn{5}{|c|}{ cięcie wiązką laserową } \\
\hline S 700MC & ferryt + bainit drobnoziarnisty & bainit drobnoziarnisty & bainit drobnoziarnisty & bainit drobnoziarnisty \\
\hline S 690QL & martenzyt odpuszczony & martenzyt niskowęglowy & martenzyt niskowęglowy & martenzyt niskowęglowy \\
\hline \multicolumn{5}{|c|}{ cięcie strumieniem wody } \\
\hline S 700MC & ferryt + bainit drobnoziarnisty & ferryt + bainit drobnoziarnisty & ferryt + bainit drobnoziarnisty & ferryt + bainit drobnoziarnisty \\
\hline S 690QL & martenzyt odpuszczony & martenzyt odpuszczony & martenzyt odpuszczony & martenzyt odpuszczony \\
\hline
\end{tabular}


Wpływ procesu cięcia na zmianę twardości przy powierzchni ciętej dla poszczególnych stali przedstawiono na rysunku 7 , natomiast na rysunku 8 pokazano porównanie rozkładu twardości w stali S 700MC oraz S 690QL w zależności od poszczególnych metod cięcia.

Przy ocenie jakości powierzchni po cięciu należy uwzględniać również kąt ukosu, sposób przebijania blachy oraz szerokość szczeliny cięcia przy górnej i dolnej powierzchni blachy. Biorąc pod uwagę właściwości eksploatacyjne elementów po cięciu, należy zwrócić też uwagę na wpływ procesów cięcia na możliwe zmiany strukturalne i chemiczne spowodowane oddziaływaniem ciepła, zwłaszcza w przypadku stali obrabianych termomechanicznie, gdzie w wyniku oddziaływania cyklu cieplnego może dojść do utraty właściwości uzyskanych w czasie obróbki cieplno-plastycznej, a w przypadku stali ulepszanych cieplnie do utwardzenia warstwy przypowierzchniowej. Szczególnie proces cięcia wiązką laserową i strumieniem plazmy powietrznej powoduje wzrost twardości w warstwie przypowierzchniowej do wartości ok. $460 \mathrm{HV}$. Proces cięcia strumieniem tlenu w obszarach strefy wpływu ciepła powoduje odpuszczanie martenzytu w przypadku stali ulepszanych cieplnie S 690QL, a w przypadku stali obrabianej termomechanicznie S 700MC prowadzi do częściowej rekrystalizacji i rozrostu ziarna. Proces cięcia strumieniem wody ze względu na swoją specyfikę nie powoduje zmian strukturalnych i chemicznych w obszarze ciętym.
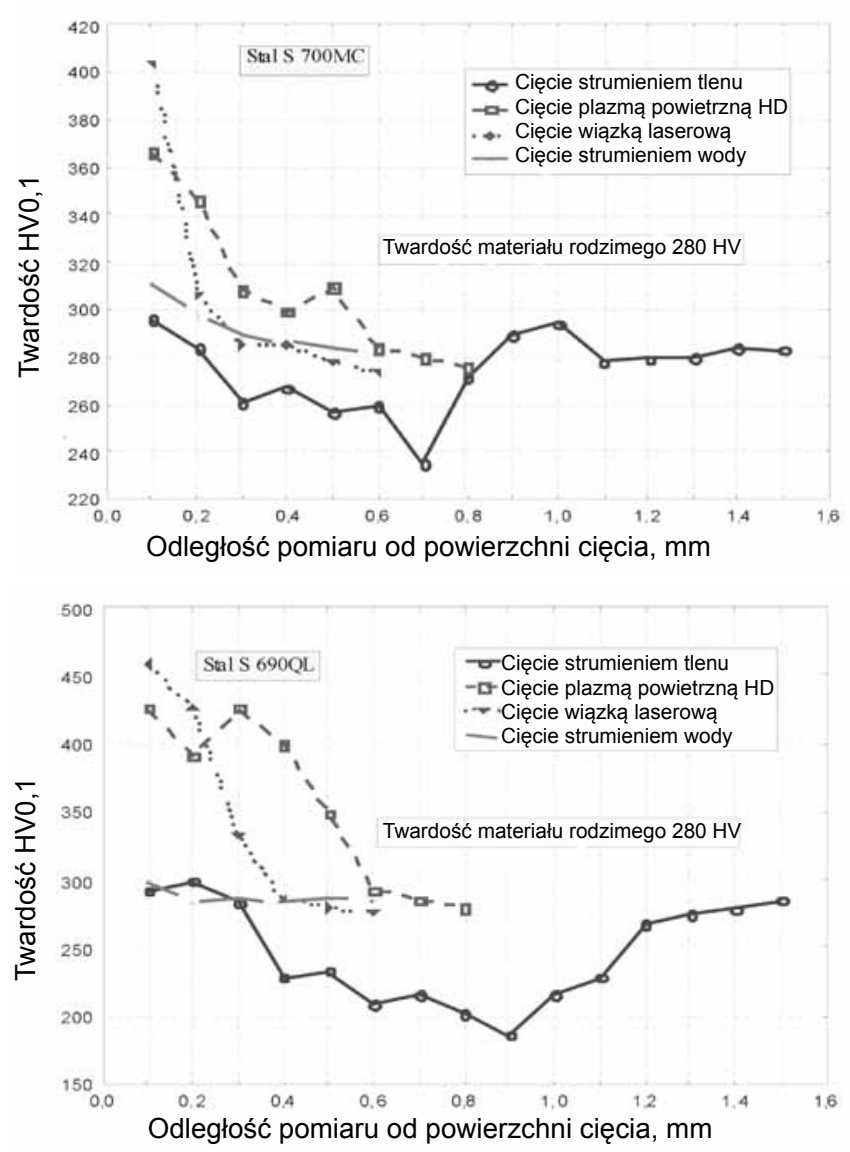

Rys. 7. Wpływ procesu cięcia na zmiany twardości w stali S 700MC i S 690QL

Fig 7. Influence of cutting process on S 700MC and S 690QL steel hardness changes

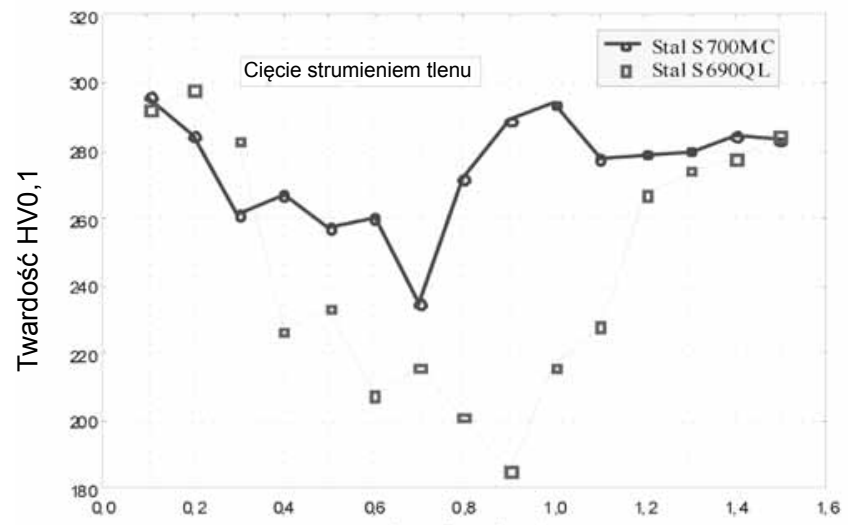

Odległość pomiaru od powierzchni cięcia, mm

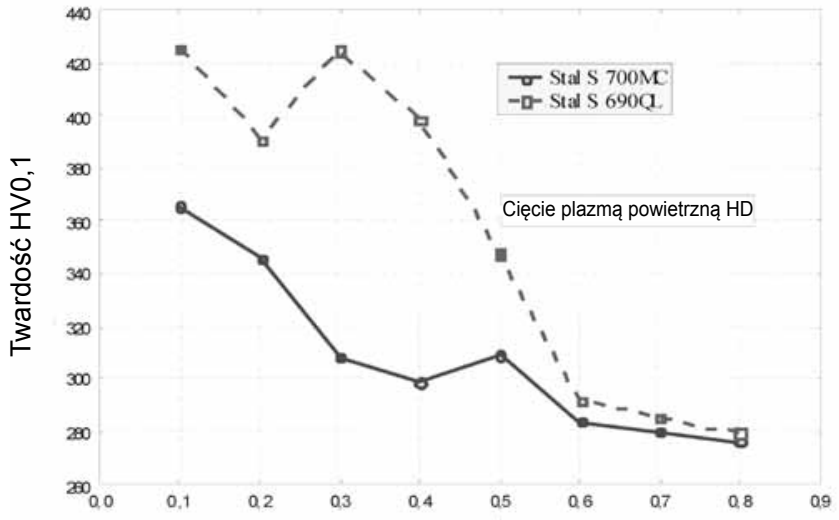

Odległość pomiaru od powierzchni cięcia, mm
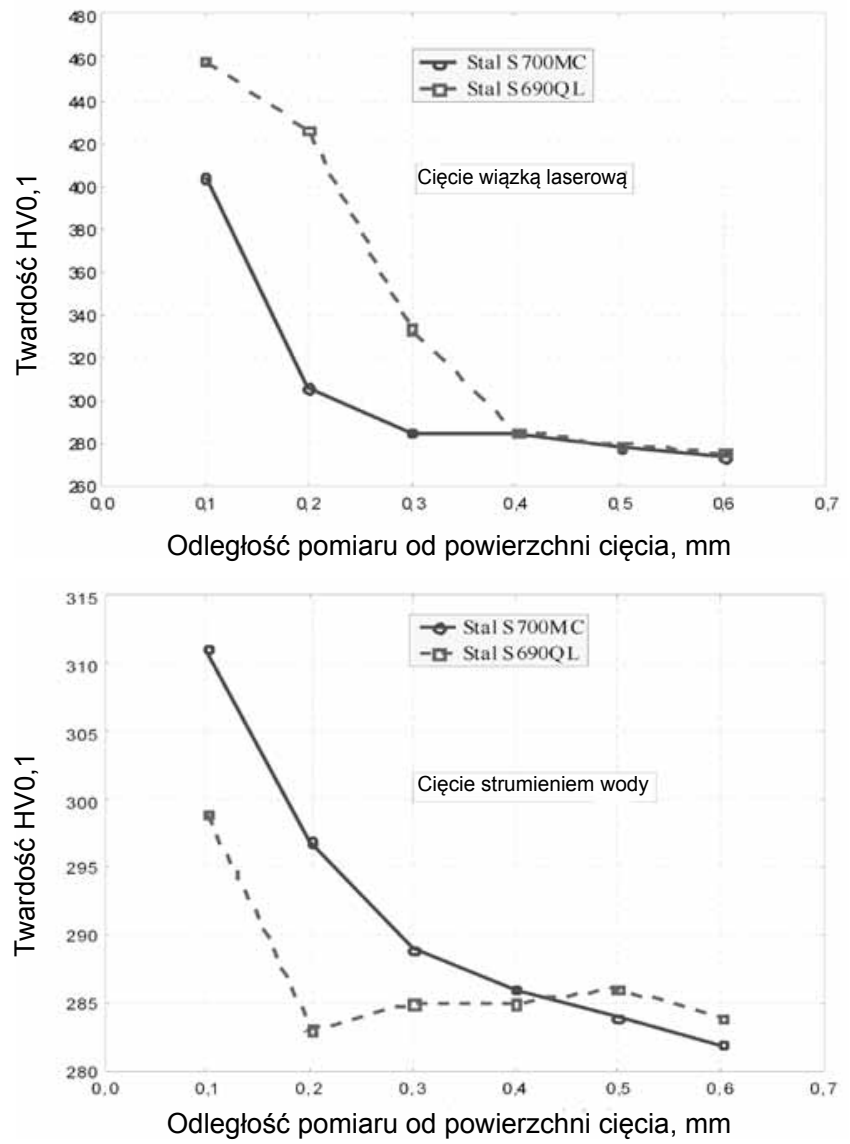

Rys. 8. Porównanie rozkładu twardości przy powierzchni cięcia w stali S 700MC i S 690QL dla poszczególnych procesów cięcia

Fig 8. Comparison of hardness distribution near the cutting surface of S $700 \mathrm{MC}$ and S $690 \mathrm{QL}$ steel for different cutting processes 


\section{Literatura}

[1] Park K. S., Cho Y. H.: Comparison of fatigue properties of welded TMCP steels and normalized steel, Pohang University of Science and Technology, Pohang, Korea 2003.

[2] Tasak E.: Metalurgia spawania, Patria Kraków 2008.

[3] Brózda J.: Nowoczesne stale konstrukcyjne i ich spawalność, Wydawnictwo Instytutu Spawalnictwa, Gliwice 2009.

[4] TMCP steel plates for building structures. Nippon Steel Corporation.

[5] Skiba J: Techniczne i ekonomiczne aspekty cięcia plazmowego. Biuletyn Instytutu Spawalnictwa, nr 5/2002 s. 77-80.

[6] Kirkpatrick I.: Profile cutting - which metod? Welding \& Metal Fabrication, October.
[7] Cool waterjet process heats up cutting market. Welding Design and Fabrication, November 2000, s. 31-33.

[8] Hidden S., Buhler B.: The Great Debate: Plasma or Oxyfuel? Welding Journal, March 2005, s. 40-44.

[9] Lamikiz A., Lopez de Lacalle: $\mathrm{CO}_{2}$ laser cutting of advanced high strength steels (AHSS). Applied Surface Science, 2004 August, s. 362-367.

[10] Burnham Chip: Waterjet advancements boost productivity. Welding Design and Metal Fabrication, June 2002, s. 24-27.

\section{Finansowanie}

Praca częściowo finansowana z grantu badawczego: „Sterowanie właściwościami i strukturą spoin stali obrabianych termomechanicznie o wysokiej granicy plastyczności”, nr N N507 321040, Politechnika Śląska w Gliwicach.

\section{Dolnośląska Sekcja Spawalnicza SIMP \\ Zakład Spawalnictwa Instytutu Technologii Maszyn i Automatyzacji i Wydział Mechaniczny Politechniki Wrocławskiej}

\section{zapraszają do udziału \\ w 4. Międzynarodowej Konferencji Naukowo - Technicznej pod hasłem "POSTEEP W TECHNOLOGIACH LUTOWANIA" WROCLAW 2013}

\section{Wrocław, 23-25 września 2013 (poniedziałek - środa) aula A1, bud. B-4 PWr, ul. Łukasiewicza 5}

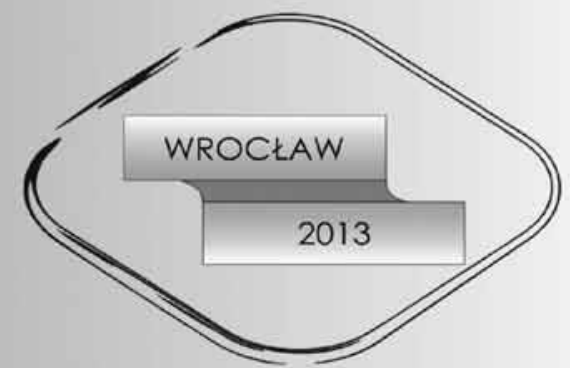

Wszystkich zainteresowanych udziałem w Konferencji prosimy o kontakt z Zakładem Spawalnictwa ITMiA Politechniki Wrocławskiej

Prof. dr hab. inż. dr h.c. Władysław Włosiński - Przewodniczący Komitetu Naukowego IV Wydzial Nauk Technicznych PAN Warszawa

Prof. dr hab. inż. Andrzej Ambroziak - Sekretarz Komitetu Naukowego tel. (071) 3202148, e-mail: andrzej.ambroziak@pwr.wroc.pl

Prof. dr hab. inż. Zbigniew Mirski - Przewodniczący Komitetu Organizacyjnego tel. (071) 3202142, e-mail: zbigniew.mirski@pwr.wroc.pl

Mgr inż. Anna Woźna - Sekretarz Komitetu Organizacyjnego tel. (071) 3202074, e-mail: anna.wozna@pwr.wroc.pl

Dr inż. Tomasz Piwowarczyk - Sekretarz Komitetu Organizacyjnego tel. (071) 3204255, e-mail: tomasz.piwowarczyk@pwr.wroc.pl

Korespondencję prosimy kierować na adres:

Komitet Organizacyjny 4. Międzynarodowej Konferencji Naukowo - Technicznej „Postęp w technologiach lutowania”

Politechnika Wrocławska, Zakład Spawalnictwa ITMiA

Wybrzeże Wyspiańskiego 27

50-370 Wrocław 